Green Politics and Neo-Liberalism 
Also by Dave Toke

\section{GREEN ENERGY}

THE LOW COST OF THE PLANET 


\section{Green Politics and Neo-Liberalism}

Dave Toke

Lecturer in Green Politics

Department of Political Science

and International Studies

University of Birmingham 


\section{MACMILLAN PRESS LTD}

Houndmills, Basingstoke, Hampshire RG21 6XS and London

Companies and representatives throughout the world

A catalogue record for this book is available from the British Library.

ISBN 978-1-349-41545-8

ISBN 978-0-230-51415-7 (eBook)

DOI $10.1057 / 9780230514157$

First published in the United States of America 2000 by

ST. MARTIN'S PRESS, LLC,

Scholarly and Reference Division,

175 Fifth Avenue, New York, N.Y. 10010

Library of Congress Cataloging-in-Publication Data

Toke, Dave.

Green politics and neo-liberalism / Dave Toke.

p. $\mathrm{cm}$.

Includes bibliographical references and index.

1. Environmental policy. 2. Rational choice theory. 3. Discourse analysis. I. Title.

GE170 .T64 2000

$363.7^{\prime} 05-\mathrm{dc} 21$

$00-042241$

\section{(C) Dave Toke 2000}

Softcover reprint of the hardcover 1st edition 2000 978-0-333-77123-5

All rights reserved. No reproduction, copy or transmission of this publication may be made without written permission.

No paragraph of this publication may be reproduced, copied or transmitted save with written permission or in accordance with the provisions of the Copyright, Designs and Patents Act 1988, or under the terms of any licence permitting limited copying issued by the Copyright Licensing Agency, 90 Tottenham Court Road, London W1P 0LP.

Any person who does any unauthorised act in relation to this publication may be liable to criminal prosecution and civil claims for damages.

The author has asserted his right to be identified as the author of this work in accordance with the Copyright, Designs and Patents Act 1988.

This book is printed on paper suitable for recycling and made from fully managed and sustained forest sources.

$\begin{array}{llllllllll}10 & 9 & 8 & 7 & 6 & 5 & 4 & 3 & 2 & 1\end{array}$

$\begin{array}{llllllllll}09 & 08 & 07 & 06 & 05 & 04 & 03 & 02 & 01 & 00\end{array}$ 
To Benjamin and James 
This page intentionally left blank 


\section{Contents}

List of Tables $\quad \mathrm{x}$

Acknowledgements $\quad$ xi

Introduction $\quad 1$

1 Discourse, Power and Environmental Policy 5

Foucault on power 9

Discursive transformation 11

The shifting self-interests of US CFC producers

and consumers 15

De-centred power is not enough 17

Transport and power 20

Alternative energy and power $\quad 26$

Truth and knowledge about US nuclear power 32

2 Rational Choice Theory and Environmental Policy 35

The fall of classic rational choice 36

RCT and 'soft' incentives $\quad 41$

Ostrom's institutional RCT 44

Belief systems, norms and self-interest 47

RCT and new international environmental problems 51

3 Science, Politics and Environmentalists 58

In the shadow of the bomb 60

From the scientisation of politics to the politicisation

$\begin{array}{ll}\text { of science } & 62 \\ \text { Scientists and environmental groups } & 64\end{array}$

Saving the whale $\quad 66$

CFCs and ozone depletion $\quad 68$

$\begin{array}{ll}\text { Beyond positivism } & 70\end{array}$

$\begin{array}{ll}\text { Blurred roles } & 72\end{array}$

4 Neo-liberalism and Green Politics $\quad 75$

$\begin{array}{ll}\text { Public choice and market theory } & 76\end{array}$

$\begin{array}{ll}\text { The norms of public choice } & 78\end{array}$

Middle classes and material self-interest $\quad 81$

$\begin{array}{ll}\text { Interpreting self-interest } & 82\end{array}$

Can green politics reinterpret self-interest? $\quad 85$ 
5 Health and Materialism $\quad 92$

Inequalities, health and social malaise 94

Stress health and work $\quad 98$

Status and the competitive society 102

Competition and consumption 105

The consequences of too much competition 106

The new discourse of stress at work 108

6 The Politics of Performance 113

Education, competition and performance 118

Does increasing competition in education work? 120

School league tables 123

Co-operative solutions 126

7 A Green Alternative $\quad 129$

A culture of stress 129

Holistic approaches to society 132

Greens and socialism 134

Gorz's green socialism - a path to paradise? 136

The shape of future work 141

Reforming work 144

Paths to holism: eastern and western 147

Paths to 'downshifting' 149

Greens and urban regeneration ${ }^{3} \quad 154$

8 Truth, Technology and Progress 159

Epistemology and ontology 161

The notion of 'species realism' 162

Human truths and environmental progress 166

Postmodernism and environmental practice 168

$\begin{array}{ll}\text { Technology and progress } & 173\end{array}$

Technology and risk 176

Three ages of control 180

9 Concluding Comments 184

Discourse and truth 184

Social green strategies $\quad 185$

$\begin{array}{ll}\text { Reconstituting self-interest } & 187\end{array}$

Rational choice and self-interest 188

$\begin{array}{ll}\text { Correcting foucault } & 189\end{array}$ 
Contents ix

Notes

191

Bibliography

193

Index

205 


\section{List of Tables}

5.1 GDP and life expectancy in selected countries (1993)

6.1 Attitudes to performance pay among UK Inland

Revenue staff 


\section{Acknowledgements}

I am greatly indebted to Dave Marsh in particular for providing me with a stimulating intellectual atmosphere and also plenty of ideas that have influenced this book. Matthew Paterson has been particularly useful in offering advice and comments. Members of the University of Birmingham's Department of Politics and International Affairs, such as Colin Hay and Peter Preston, have also been helpful and influential in various ways. Helpful comments have been received from others, including Robert Garner, Stuart McAnulla, Mike Davies, Horace Herring, Mike Cross and Dave Humphreys.

DAve TOKE 